\title{
Uma solução viável para a reciclagem de resíduos industriais de ardósia em pavimentação
}

\begin{abstract}
O presente artigo discorre sobre pesquisa acerca do uso de material alternativo, ambientalmente inerte, caso dos rejeitos industriais britados de ardósia, fisicamente transformados em agregados, como integrantes das camadas granulares e de revestimento de um pavimento asfáltico. Trata-se uma solução viável, do ponto de vista técnico e ambiental, para a reciclagem deste tipo de material em pavimentos asfálticos, contribuindo para a mitigação de impactos ambientais decorrentes da exploração da ardósia - rocha ornamental - na maior província do mundo de ocorrência deste tipo de litológico. O estudo está centrado na construção de uma pista em um trecho experimental, no município de Papagaios, MG, para acompanhamento de seu desempenho ao longo do tempo. Os agregados de ardósia foram preliminarmente submetidos aos ensaios de caracterização física e química. Como integrantes de um sistema de camadas, esses agregados, em mistura solo-brita graduada simples, e em mistura com cimento asfáltico de petróleo (CAP 50/70), foram também submetidos aos ensaios de caracterização mecânica e de cargas cíclicas, no contexto da mecânica dos pavimentos. Os resultados encontrados permitiram constatar que o material por si mesmo é resistente à meteorização, e do ponto de vista geotécnico, resistente ao desgaste por abrasão e ao ataque químico, possui baixa absorção, baixa degradação com e sem ligante, baixa presença de finos plásticos e satisfatória adesividade a ligante asfáltico. Os parâmetros volumétricos da metodologia Marshall, como também estabilidade e resistência à tração, integralmente atendidos, não o invalidam para uso rodoviário, inclusive no capeamento asfáltico, em misturas a quente. Aplicado o novo método de dimensionamento nacional - MeDiNa, este prognosticou um bom desempenho da pista do trecho experimental para seu período de projeto. A utilização de ardósia, como material de pavimentação, empregado na Região Central de Minas Gerais, onde é abundante, evitará exploração de novas jazidas de agregados convencionais, e concorrerá para emprego e renda na região, com maior sustentabilidade ambiental.
\end{abstract}

Palavras-chave: Resíduos de Ardósia; Mecânica de Pavimentos; MeDiNa; Sustentabilidade Ambiental.

\section{A viable solution for recycling industrial slate waste applied in pavements}

\begin{abstract}
This article discusses research on the use of alternative, environmentally inert material, such as industrial crushed slate waste, physically transformed into aggregates, as part of the granular and coating layers of an asphalt pavement. From a technical and environmental point of view, it is a viable solution, , for recycling this type of material in asphalt pavements, contributing to the mitigation of environmental impacts resulting from the exploitation of slate - ornamental rock - in the largest province in the world where this lithological type occurs. The study is centered on the construction of a segment in an experimental track, in Papagaios' District, state of Minas Gerais, Brazil, to monitor its performance over time. The slate aggregates were centered on the construction of a segment in an experimental track, in Papagaios' District, state of Minas Gerais, Brazil, to monitor its performance over time. The slate aggregates were
preliminarily subjected to physical and chemical characterization tests. As part of a layer system, these aggregates, in a simple graduated soil-crushed mixture, and in mixture with petroleum preliminarily subjected to physical and chemical characterization tests. As part of a layer system, these aggregates, in a simple graduated soil-crushed mixture, and in mixture with petroleum
asphalt cement (CAP 50/70), were also subjected to mechanical characterization and cyclic loads tests, in the context of pavement mechanics. The results found showed that the material is asphalt cement (CAP 50/70), were also subjected to mechanical characterization and cyclic loads tests, in the context of pavement mechanics. The results found showed that the material is resistant to weathering, and from a geotechnical point of view, resistant to abrasion and chemical attack, it has low water absorption, low degradation with and without binder, low presence invalidate it for ratisfactory adhesion to asphalt binder. The voluplied the new Brazilian method of dimensioning asphalt pavements - MeDiNa, this predicted a good performance of the segment of the experimental stretch for its project period. The use of slate, as paving material, used in the Central Region of Minas Gerais State, where it is abundant, will prevent the exploration of new quarries of conventional aggregates, and will compete for employment and income in the region, with environmental sustainability.
\end{abstract}

Keywords: Slate Residues; Pavement Mechanics; MeDiNa; Environmental Sustainability.

Topic: Engenharia Ambiental

Reviewed anonymously in the process of blind peer.

Marco Antônio das Graças Antunes

Universidade Federal de Ouro Preto, Brasil

http://lattes.cnpq.br/3577873653663308

http://orcid.org/0000-0002-8208-2577

marcoantonioantunes56@gmail.com

Antonio Carlos Rodrigues Guimarães (iD Instituto Militar de Engenharia, Brasil http://lattes.cnpq.br/8890983301899546 http://orcid.org/0000-0001-9244-7034 guimaraes@ime.eb.br

Geraldo Luciano de Oliveira Marques (iD) Universidade Federal de Juiz de Fora, Brasi http://lattes.cnpq.br/4503245454189660

http://orcid.org/0000-0003-1347-2624 geraldo.marques@ufjf.edu.br
Received: 01/05/2020

Approved: 03/06/2020
Referencing this:

ANTUNES, M. A. G.; GUIMARÃES, A. C. R.; MARQUES, G. L. O.. Uma solução viável para a reciclagem de resíduos industriais de ardósia em pavimentação. Revista Ibero-Americana de Ciências Ambientais, v.11, n.4, p.236-254, 2020. DOI: http://doi.org/10.6008/CBPC2179$\underline{6858.2020 .004 .0021}$ 


\section{INTRODUÇÃO}

A oportunidade de se utilizar agregado alternativo, ambientalmente inerte, caso dos resíduos industriais britados de ardósia, adequado à finalidade de construção, conservação e manutenção rodoviária, poderá viabilizar financeiramente obras com emprego de capeamento asfáltico usinado a quente, em vias de baixos e médios volumes de tráfego, na região Central de Minas Gerais/MG, onde se encontra a 'Província de $\operatorname{Ardósia}^{\prime 1}$. Nesta região, o destaque é o município de Papagaios, pela abundancia e facilidade de extração da rocha. A afirmação de que a característica 'lamelar' do material britado de ardósia, em princípio, constituiria restrição técnica para seu emprego rodoviário, não é um impeditivo para seu uso, conforme resultados dos ensaios mostrados neste artigo.

Os resíduos do beneficiamento de ardósia, há duas décadas, eram inadequadamente dispostos à beira de rodovias, Figura 1, nos municípios integrantes da referida Província. Gerado em grandes volumes, esses resíduos formavam morros artificias, com impacto visual à paisagem, soterramento de nascentes e áreas de recarga, entre outros agravos; com sérios prejuízos ao meio ambiente. Mediante um programa de boas práticas ambientais, liderado pela Fundação Estadual de Meio Ambiente - FEAM/MG, o reaproveitamento e a reciclagem desses materiais foram implementados e têm sido eficazes como medidas de controle ambiental.

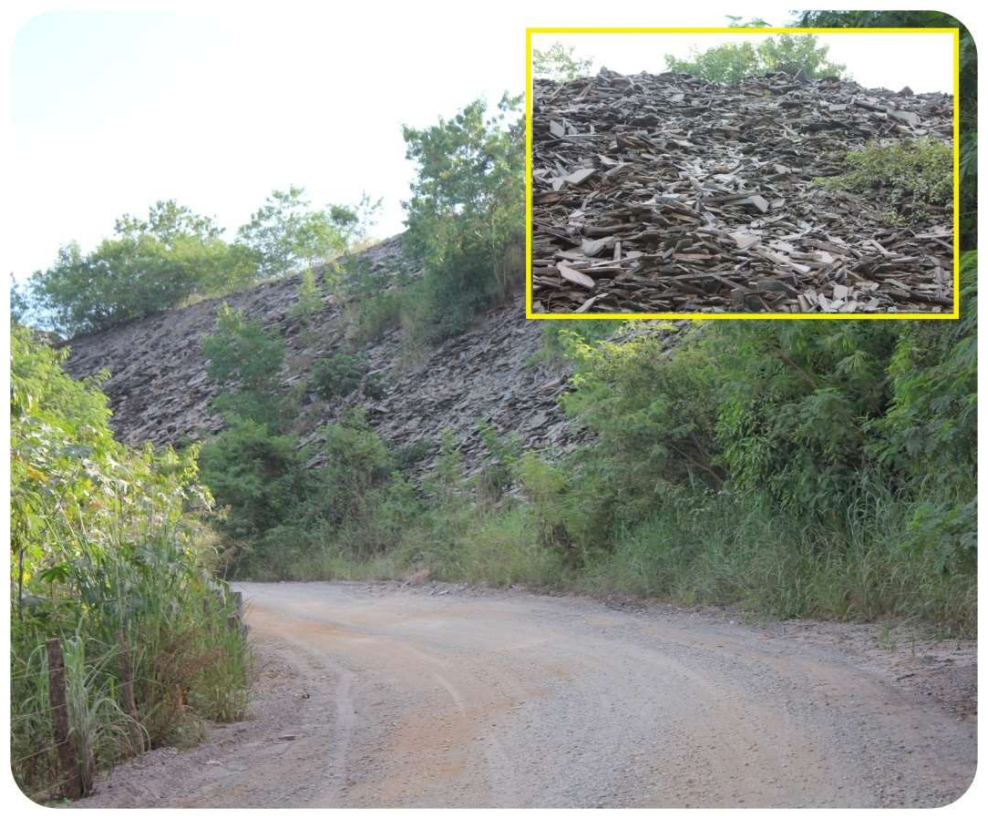

Figura 1: Resíduos de ardósia dispostos inadequadamente.

Atualmente, em Papagaios, todo o material decorrente das sobras do beneficiamento de ardósia é retirado das serrarias, onde é gerado, por empresa recicladora local, o que vem proporcionando emprego e renda para o município com a venda de material britado em granulometrias diversas para os mais diferenciados usos e aplicações; entre esses, 'encascalhamento' de vias rurais (com bica corrida), confecção

\footnotetext{
1 Província de Ardósia de MG: compreende total ou parcialmente os municípios de Papagaios, Curvelo, Pompéu, Paraopeba, Caetanópolis, Felixlândia, Leandro Ferreira, Martinho Campos e Pitangui e abrange uma extensão territorial contínua da ordem de 7.000 km2, na Região Central do Estado de Minas Gerais, sendo o município de Papagaios o destaque, considerando-se as atividades de extração e de beneficiamento. Minas Gerais responde por $94 \%$ da produção nacional de ardósia e Papagaios por $84 \%$ dessa produção.
} 
de blocos de concreto (com pó de pedra), insumo para fabricação de concreto cimento Portland (com brita 2) e remineralização de solo (com partículas finas). O emprego desse material, se aprovado por órgão rodoviário, despertará demanda para seu uso corrente em vias de comunicação e transporte, e certamente fomentará a economia regional.

Para Nunes et al. (1996), os principais benefícios esperados com o uso de materiais alternativos na construção (disponibilizados como resíduos industriais de outros processos) podem ser sintetizados pela redução de: demanda por agregados minerais convencionais; custos associados a essa extração; custos ambientais associados à exploração de pedreiras; custos associados à necessária disposição ambientalmente correta desses resíduos. Há, ainda, a agregação de valor aos resíduos alternativos, em geral sem finalidade econômica.

No Brasil e no mundo, há escassos estudos sobre o uso do material britado de ardósia em pavimentos rodoviários. A pesquisa que enseja a publicação deste artigo vem prosseguir, em termos de ensaios mecânicos e análise mecanicista, os trabalhos pioneiros de Pires (2006), que empregou concreto asfáltico, com agregados britados de ardósia, em camada de reforço na BR 040, próximo da cidade de Três Marias, MG, no ano de 2006, e de Rodrigues (2009), cuja pesquisa acadêmica veio a incentivar, a partir de 2011, o uso desses agregados em mistura asfáltica a frio - PMF, no contexto do programa municipal de capeamento e recapeamento asfáltico na cidade de Fortuna de Minas, MG. No exterior, o uso de ardósia em pavimentos se destaca no Reino Unido, com resíduos britados de ardósia empregados nas camadas subjacentes à do revestimento, sobretudo na sub-base (DAWSON et al., 1993). O presente artigo tem por objetivo apresentar as propriedades geotécnicas do material britado de ardósia sob os ensaios de caracterização, mecânicos e análise mecanicista, para uso rodoviário. Aplicar o Método MeDiNa e abordar sobre a construção de um trecho experimental, parte integrante da pesquisa.

\section{REVISÃO TEÓRICA}

Balbo (2007) define o pavimento como:

[...] uma estrutura não perene, composta por camadas sobrepostas de diferentes materiais compactados a partir do subleito do corpo estradal, adequada para atender estrutural e operacionalmente ao tráfego, de maneira durável e ao mínimo custo possível, considerados diferentes horizontes para serviços de manutenção preventiva, corretiva e de reabilitação, obrigatórios.

Medina et al. (2015) ensinam que dimensionar um pavimento não se limita à determinação das espessuras de suas camadas, mas também e necessariamente à verificação da compatibilização de seus materiais, pois se trata de um sistema que funciona em conjunto. Para se definir materiais e espessuras de um pavimento, devem-se levar em conta parâmetros como tráfego esperado, clima, topografia, subleito, drenagem, técnicas construtivas e critérios de rupturas. Os autores asseguram que a durabilidade de uma estrutura de pavimento não pode ser controlada por métodos empíricos, pois nestes não há elementos que permitam quantificar o estado de tensões atuantes na estrutura e, por conseguinte, deixam de avaliar fatores determinantes para o seu desempenho, como é o caso da tensão de tração na face inferior do revestimento e a tensão vertical no topo da camada final, portanto, o subleito. 
Bernucci et al. (2010) argumentam que os principais danos ocorrentes nos pavimentos asfálticos, caso de trincas de fadiga e de deformação permanente em trilha de roda, não se apresentam de forma súbita, mas sim ao longo do tempo, a partir da abertura ao tráfego. O carregamento transiente com a passagem de veículos induz ao pavimento um deslocamento com duas componentes: deformação elástica ou resiliente (que resulta da flexão alternada do revestimento) e deformação plástica ou permanente (que resulta no afundamento de trilha de roda).

A deformação resiliente de misturas asfálticas e de solos pode ser determinada a partir do cálculo do Módulo de Resiliência (MR), parâmetro fundamental da mecânica de pavimentos, e que expressa a razão entre tensão e deformação de materiais submetidos a carregamento cíclico. No caso primeiro, tem-se a relação entre a tensão de tração ( $\sigma \tau)$ aplicada repetidamente no plano vertical de uma amostra cilíndrica de mistura asfáltica e a deformação específica recuperável de tração ( ${ }^{\varepsilon \tau}$ ), DNIT 135 (2018). No segundo, tem-se a relação entre a tensão desvio ( $\sigma d$ ), aplicada repetidamente numa amostra de corpo de solo ou de solo mais agregados, e a correspondente deformação vertical recuperável ou resiliente ( $E r$ ), DNIT 134 (2018). Mostra-se, nas Equações (1) e (2), respectivamente, a expressão matemática de ambos os casos.

$$
\begin{aligned}
& \mathrm{M}=\frac{\sigma \tau}{\varepsilon \tau} \\
& \mathrm{M}=\frac{\sigma d}{\varepsilon r}
\end{aligned}
$$

Marques (2004) propôs a utilização do módulo de resiliência como indutor do critério de dosagem para misturas asfálticas. Essa consideração visa aferir preliminarmente a escala de grandeza do módulo de resiliência da camada do revestimento, com a maior rigidez do pavimento asfáltico. Módulos de resiliência muito altos para o revestimento asfáltico, em relação a módulos de resiliência relativamente baixos, para camadas granulares, subjacentes, deixam o sistema de camadas vulnerável quanto à rigidez muito diferenciadas, perdendo-se a condição de trabalhabilidade conjunta do pavimento; o que pode gerar trincas superficiais prematuras no revestimento asfáltico.

Por outro lado, a deformação permanente (DP) ou plástica é a parcela não recuperável da deformação total ou do deslocamento total do pavimento, cumulativa ao longo do tempo pela contribuição individual de cada uma das camadas do pavimento, DNIT 179-IE (2018). Esse tipo de patologia com repercussão funcional e estrutural no pavimento é denominado de afundamento de trilha de roda (ATR), e o modelo genérico de dano, atribuído a Barksdale (1972) está representado pela Equação (3). Deve-se também a esse pesquisador a propositura conceitual de que o pavimento funciona como um sistema de camadas Lima (2016).

$$
\delta_{\text {total }}^{p}=\sum_{i=1}^{n} \varepsilon_{p}^{i} h_{i}
$$

Onde: $\delta_{\text {total }}^{p}=$ Profundidade total do afundamento na superfície do pavimento (afundamento de trilho de roda); $\varepsilon_{p}^{i}=$ Deformação específica plástica da i-ésima camada; $h_{i}=$ Espessura da i-ésima camada; e $\mathrm{n}=$ Número total de camadas. 
Guimarães (2009) aprimorou o modelo de Barksdale (1972) para o caso de solos tropicais brasileiros, em razão da forte influência do intemperismo - principalmente químico - na geomorfologia do país. O modelo de Guimarães (2009) apresentado na Equação (4) se insere no contexto moderno da mecânica de pavimentos, pois considera a deformação permanente em função de parâmetros como deformabilidade, tensão confinante, tensão desvio e do número de ciclos de repetição de cargas transientes.

$$
\varepsilon_{p}(\%)=\psi_{1} \cdot\left(\frac{\sigma_{3}}{\rho_{0}}\right)^{\psi_{2}} \cdot\left(\frac{\sigma_{d}}{\rho_{0}}\right)^{\psi_{3}} . N^{\psi_{4}}
$$

Onde: ${ }^{\varepsilon_{p}(\%)}=$ Deformação permanente específica; $\psi_{1,2,3,4}=$ Parâmetros de Regressão; $\sigma_{3}=$ Tensão confinante; $\sigma_{d}$ = Tensão desvio; ${ }^{\rho_{0}}=$ Tensão de referência (tensão atmosférica); e N = Número de ciclos de aplicação de carga. A necessidade de se estabelecer uma nova metodologia de dimensionamento nacional para pavimentos asfálticos resultou no método denominado $\mathrm{MeDiNa}^{2}$, sucessor do SISPAV, de autoria de Franco (2007). O motivo também está associado à dimensão continental do país, por apresentar diversas classes de solos e climas regionais, e da necessidade de se atualizar o perfil das composições do tráfego (com veículos combinados nas mais diversas configurações e pesos), bem mais severas para o pavimento do que aquelas concebidas nas décadas de 1950/1960. O Método do CBR, essencialmente empírico, conhecido como o 'Método do Murillo', e que ainda vigora, será naturalmente substituído pelo MeDiNa, à medida que as especificações técnicas de projeto e serviço o adotarem em definitivo.

O MeDiNa pode ser aplicado por meio de um software destinado à realização do dimensionamento mecanístico-empírico de estruturas de pavimentos asfálticos por meio da rotina $\mathrm{AEMC}^{3}$, que permite calcular tensões e deformações atuantes nessas estruturas sob a passagem do eixo rodoviário padrão nacional (eixo simples de roda dupla de $80 \mathrm{kN}$ ou 8,2 tf) e aplicar modelos de fadiga e de deformação permanente de forma a ajustar condizentemente as espessuras das camadas ao carregamento imposto. Por sua vez, o BackMeDiNa é um software complementar ao MeDiNa e visa retroanalisar bacias de deformação obtidas pela passagem do equipamento FWD (Falling Weigth Deflectometer) em pista, com objetivo de inferir sobre a magnitude do módulo de resiliência in situ de cada uma das camadas em caso de reforço do pavimento Souza Júnior (2018).

\section{METODOLOGIA}

\section{Materiais}

A Associação Brasileira da Indústria de Rochas Ornamentais define ardósias como se segue:

Ardósias (slates) são rochas metassedimentares, de baixo grau metamórfico, formadas a partir de sequências argilosas e síltico-argiloas. Seus principais constituintes mineralógicos incluem mica branca fina (sericita), quartzo, clorita e grafita. Sendo essencialmente constituídas de minerais estáveis, como o quartzo e os filossilicatos (mica e clorita), as ardósias são resistentes à meteorização e por isso bastante duráveis. (ABIROCHAS, 2009).

Enquanto material rochoso, a caracterização mineralógica (identificação de fases cristalinas) das amostras de ardósia pesquisadas foi realizada por meio de Difratometria de Raios $\mathrm{X}$, pelo Método do pó, no 
CDTN - Centro de Desenvolvimento de Tecnologia Nuclear, em Belo Horizonte, e cujo resultado de três amostras de rocha em pó está apresentado na Tabela 1.

Tabela 1: Difratometria de Raios-X (Ardósia).

\begin{tabular}{lllllll}
\hline Material Ardósia em pó & \multicolumn{2}{l}{ Método do pó } \\
Fonte: Ardósia Reis, Papagaios/MG & \multicolumn{1}{l}{ Componentes das fases cristalinas principais identificadas } \\
\cline { 2 - 7 } & Quartzo & Calcita & Muscovita & Clorita & Albita & Clinocloro \\
& $\%$ & $\%$ & $\%$ & $\%$ & $\%$ & $\%$ \\
\hline Ardósia resíd. matacão & 45,6 & 1,4 & 3,9 & 26,3 & 20,2 & 2,6 \\
Ardósia resíd. exportação & 35,0 & 15,6 & 11,0 & 16,5 & 15,2 & 6,7 \\
Ardósia resíd. pó decantado & 41,5 & 10,9 & 25,9 & 16,8 & 4,9 & \\
\hline
\end{tabular}

Os materiais transformados fisicamente e mecânicamente, de especial interesse à pesquisa, na forma de agregados são: brita 1, brita 0 (resíduo misturado), brita 0 (resíduo matacão ${ }^{4}$ ), pó de pedra e pó decantado. Os quatro primeiros decorrem do processo seletivo de cominuição de resíduos como chapas quebradas, cacos e aparas, após a passagem por britadores de mandíbulas, em dois estágios. O pó decantado, como o nome já o diz, resulta da decantação do material sólido presente da polpa gerada durante o corte a úmido em peças no estágio de beneficiamento (esquadrejamento). Esses quatro materiais estão ilustrados na Figura 2, e foram fornecidos pelas empresas Pevex (central de britagem e comercialização de material britado de ardósia) e Ardósia Reis (empresa de mineração, com atividades de lavra, beneficiamento, britagem e comercialização de produtos de ardósia), ambas instaladas no município de Papagaios/MG.
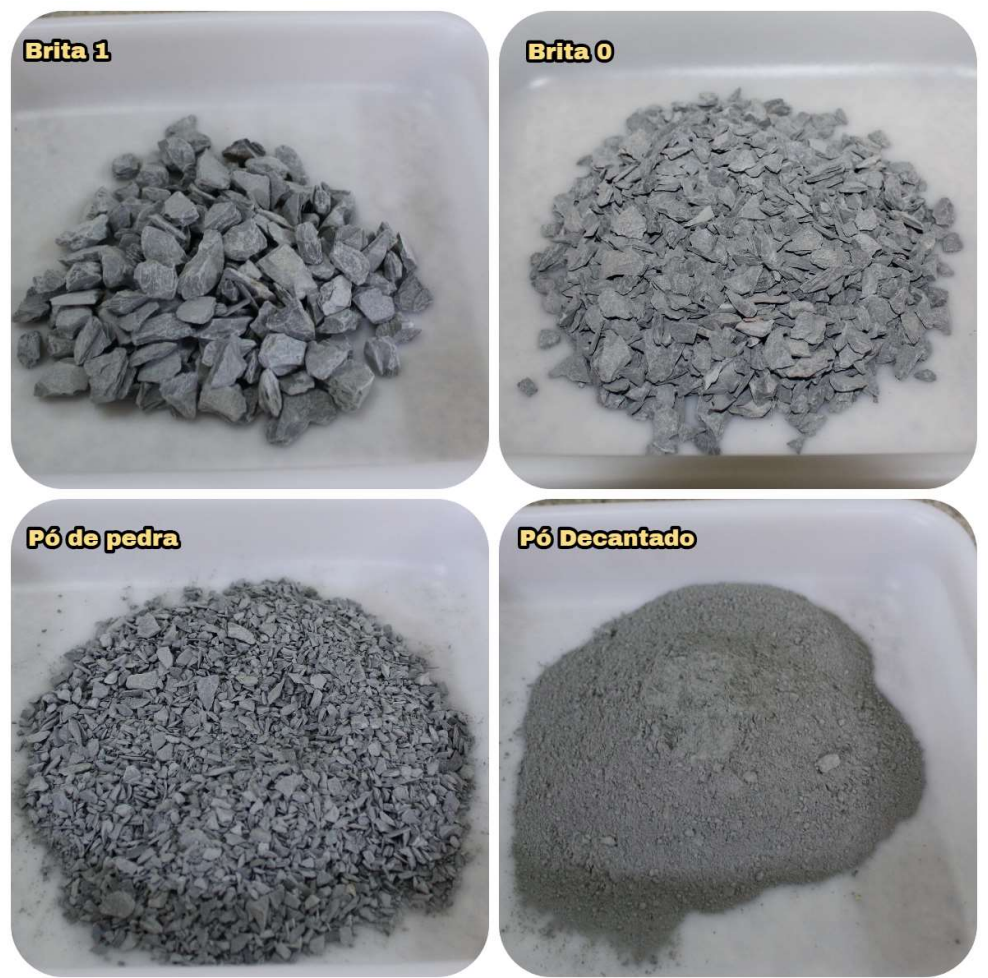

Figura 2: Material britado e decantado de ardósia.

Na Figura 3, estão mostradas as curvas granulométricas dos agregados: brita 1, brita 0 (matacão), brita 0 , pó de pedra e pó decantado de ardósia. 


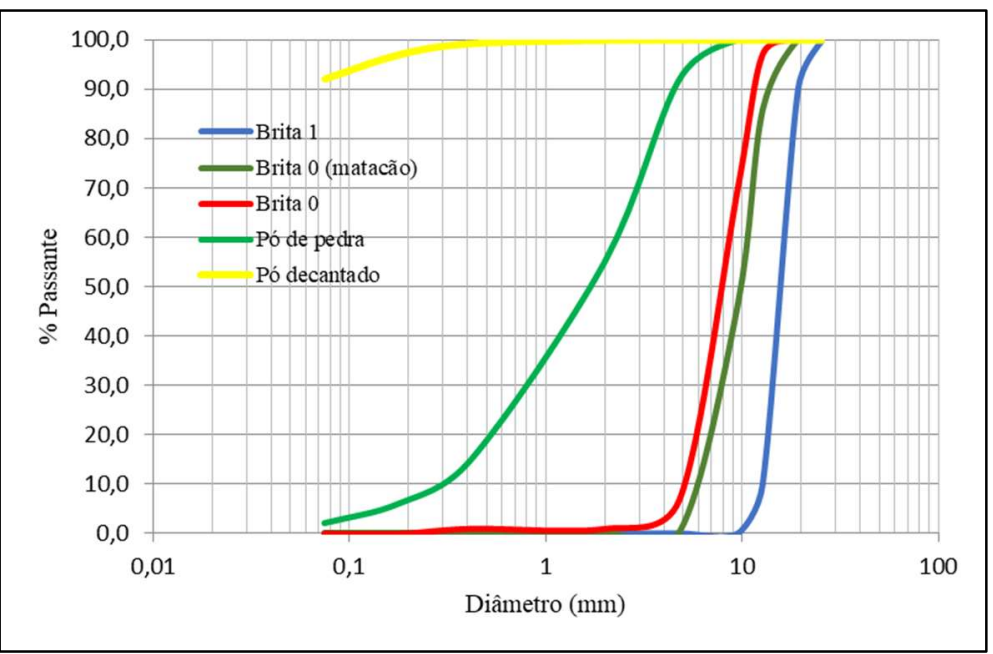

Figura 3: Curvas granulométricas dos agregados de ardósia.

No sentido de se certificar a qualidade dos agregados de ardósia, enquanto material pétreo para fins rodoviários, estes foram preliminarmente submetidos a ensaios de natureza física e química, como massa específica real, massa unitária, índice de forma, absorção, equivalente de areia, resistência à abrasão, degradação, durabilidade, ataque químico e adesividade ao ligante asfáltico, conforme mostrado na Tabela 2 , a qual apresenta resultados médios de acordo com as normas específicas.

Tabela 2: Características físicas e químicas dos agregados de ardósia.

\begin{tabular}{|c|c|c|c|c|}
\hline Ensaios & $\begin{array}{l}\text { Brita } \\
1\end{array}$ & $\begin{array}{l}\text { Brita } \\
0\end{array}$ & $\begin{array}{l}\text { Pó de } \\
\text { pedra }\end{array}$ & $\begin{array}{l}\text { Pó } \\
\text { decantado }\end{array}$ \\
\hline Massa específica real (g/cm3) & 2,767 & 2,765 & 2,771 & 2,791 \\
\hline Massa unitária $(\mathrm{g} / \mathrm{cm} 3)$ & 1,371 & 1,380 & 1,681 & 1,522 \\
\hline Índice de forma: ardósia, resíduo misturado & 0,56 (“B”) & 0,49 (“D”) & & \\
\hline Índice de forma: ardósia, resíduo matacão & 0,74 (“B”) & 0,54 (“D”) & & \\
\hline Absorção (\%) & 0,57 & & & \\
\hline Equivalente de areia (\%) & & & 76,9 & \\
\hline Abrasão Los Angeles (\%) & 17,6 (“B”) & & & \\
\hline Índice de degradação com ligante (IDML)(\%) & 1,34 & 1,34 & & \\
\hline Índice de degradação sem ligante (IDM)(\%) & 2,1 & 2,1 & & \\
\hline Durabilidade do agregado (ao sulfato de magnésio) (\%) & 0,27 & & & \\
\hline Adesividade ao ligante (CAP 50/70) & Satisfatório & Satisfatório & & \\
\hline
\end{tabular}

\section{Métodos}

O programa metodológico da pesquisa compreendeu quatro etapas, conforme segue: ensaios de caracterização física e química dos materiais pétreos envolvidos; caracterização mecânica das misturas soloagregados de ardósia; caracterização mecânica das misturas ligante asfáltico-agregados de ardósia; aplicação da ferramenta MeDiNa (para previsão do desempenho, ao longo do período de projeto, de uma pista em trecho experimental, idealizada); e, por último, a construção da própria pista, com recursos locais. Ressaltasse que avaliação pormenorizada dos aspectos funcionais e estruturais da referida pista ainda está prematura para ser realizada.

Ensaios de caracterização física de agregados, solos e misturas de agregados e solos

Os ensaios seguiram as seguintes normais técnicas: preparação para ensaio de solos ABNT-NBR 6557 
(2016), análise granulométrica por peneiramento ABNT-NBR 7181 (2016), determinação do limite de liquidez ABNT-NBR 6459 (2016), determinação do limite de plasticidade ABNT-NBR 7180 (2016), determinação da absorção e da massa específica do agregado graúdo DNER-ME 195 (1997); Agregado miúdo - determinação da densidade real DNER-084 (1995), agregado em estado solto - determinação da massa unitária DNER-ME 152 (1995); equivalente de areia DNER- ME - 054 (1997); índice de forma do agregado DNER- ME 086 (1994); abrasão Los Angeles DNER-ME 035(1998); durabilidade do agregado DNER-ME 089 (1994); base estabilizada granulometricamente DNER 141 (2010); sub-base estabilizada granulometricamente DER-SP ET-DE: P00/008 (2015); índice de degradação de rocha DNER-ME 401 (1999); perda de massa por imersão DNER-ME 256 (1994); e solo compactado em equipamento miniatura DNER - ME 258 (1994).

Ensaios de caracterização mecânica de misturas de agregados e solos e de agregados e ligantes asfálticos

Esses ensaios seguiram as seguintes normais técnicas: Expansibilidade DNIT - 160 (2012), compactação ABNT-NBR 7182 (2016), índice de suporte Califórnia (ISC/CBR), ABNT-NBR 9895 (2016), adesividade do agregado graúdo a ligante betuminoso DNER - ME 078 (1994), ensaio Marshall DNER - ME 043 (1995)

\section{Ensaios de caracterização mecânica de solos e de misturas asfálticas}

Os ensaios seguiram as seguintes normais técnicas: Módulo de resiliência - solos DNIT - 134 (2018), módulo de resiliência - misturas asfálticas DNIT - ME 135 (2018), resistência à tração DNIT - 136 (2018), fadiga DNIT - ME 183(2018), deformação permanente - solos DNIT 179 (2018).

\section{MeDiNa}

Método de dimensionamento nacional de pavimentos asfálticos (última versão: 1.1.3.0 - set/2019).

\section{Construção do Trecho experimental}

O trecho experimental construído em Papagaios, ao final de 2017, é acessado diretamente pela rodovia estadual MG 423 e tem uma extensão de $260 \mathrm{~m}$, por 6,50m a 7,00m de largura (pista simples, mão dupla, sem faixa demarcatória) e integra a Rua Dona Benedita, num contexto viário total 'alça' com aproximadamente $2.970 \mathrm{~m}$, alvo do programa municipal de asfaltamento viário de 2017 para a comunidade do Distrito de Vargem Grande, Papagaios (Figura 4).

$\mathrm{Na}$ localidade do trecho experimental a topografia se mostra suave ondulada, a drenagem natural da pista tem seu escoamento lateralmente dirigido para um pasto. À abertura de trincheiras, em cota superior a 1,5m, não se constatou presença de água. O clima no município de Papagaios é mesotérmico sub-úmido IBGE (2020), no qual o inverno é seco e o verão quente e úmido, com distribuição esparsa das chuvas. A vegetação corresponde ao cerrado (embora já esteja descaracterizada), com pouca arborização e que cedeu lugar a pastagem.

A função predominante da via é 'local', o tipo de tráfego é 'leve', com um volume médio diário (VMD) 
estimado para o primeiro ano (2018) de abertura ao tráfego de 25 caminhões (ESRD, 80 kN), em um sentido. Para a inserção do pavimento asfáltico, as camadas originais de base (pedregulho areno siltoso) e sub-base (pedregulho areno argilo siltoso amarelo) foram retiradas. Em substituição, foram construídas as respectivas camadas, estabilizadas granulometricamente. As obras do trecho experimental foram divididas entre o município de Papagaios, que se encarregou da construção das camadas granulares, e ao Estado, por meio de empreiteira, ficou o encargo das obras de capeamento asfáltico.

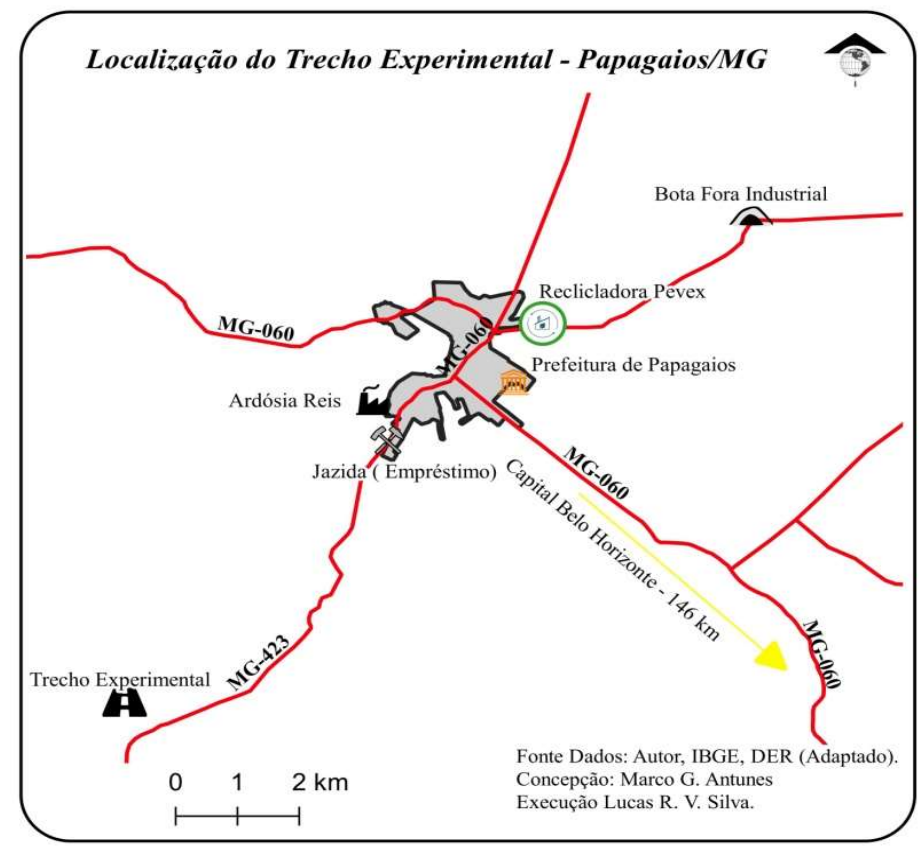

Figura 4: Mapa de localização do trecho experimental.

Os solos, materiais acessórios da pesquisa, utilizados como integrantes das camadas granulares, caracterizados na Tabela 3, foram misturados em pista com os agregados de ardósia, sendo esses: do próprio subleito do trecho experimental e de área de empréstimo, lindeira à rodovia MG 423, próxima da sede do município, catalogada pelo órgão rodoviário do Estado e única disponível localmente. E, por último, para a camada de rolamento, os materiais (ligantes asfálticos) foram o cimento asfáltico de petróleo CAP 50/70, utilizado na composição do revestimento, Mistura 1 e Mistura 2; o asfalto diluído de cura média, CM 30, utilizado na impermeabilização da camada de base; e a pintura de ligação de ruptura rápida, RR $1 C$, para aderência entre a camada de base e a capa asfáltica, materiais esses fornecidos e aplicados no trecho experimental por empreiteira da região, que dispõe de usina de asfalto.

Tabela 3: Caracterização geotécnica dos solos utilizados nas camadas granulares da pista do trecho experimental.

\begin{tabular}{|c|c|c|c|c|c|c|c|c|c|c|}
\hline \multirow{3}{*}{$\begin{array}{l}\text { Material } \\
\text { solo }\end{array}$} & \multicolumn{4}{|c|}{ AASHTO-M 145-91 } & \multirow{2}{*}{\multicolumn{2}{|c|}{$\begin{array}{l}\text { MCT } \\
\text { Coeficientes }\end{array}$}} & \multicolumn{4}{|c|}{ COMPACTAÇÃO PROCTOR NORMAL } \\
\hline & LL & IP & IG & GRUPO & & & \multirow{2}{*}{$\begin{array}{l}\text { W (\%) } \\
\text { ótima }\end{array}$} & \multirow{2}{*}{$\begin{array}{l}\text { MEAS } \\
\mathrm{g} / \mathrm{cm} 3\end{array}$} & \multirow{2}{*}{$\begin{array}{l}\text { CBR } \\
\%\end{array}$} & \multirow{2}{*}{$\begin{array}{l}\text { EXPANSÃO } \\
\%\end{array}$} \\
\hline & $\%$ & $\%$ & & & $c^{\prime}$ & $\mathrm{e}^{\prime}$ & & & & \\
\hline Subleito & 47 & 20 & 13 & A-7-6 & 1,93 & 1,08 & \multirow[t]{2}{*}{27,5} & \multirow[t]{2}{*}{1,425} & \multirow[t]{2}{*}{10} & \multirow[t]{2}{*}{0,01} \\
\hline Classificação & \multicolumn{4}{|c|}{ Argila areno siltosa } & \multicolumn{2}{|c|}{ LG'argiloso lat. } & & & & \\
\hline Empréstimo & 30 & 14 & 5 & $A-6$ & & & \multirow[t]{2}{*}{15,2} & \multirow[t]{2}{*}{1,729} & \multirow[t]{2}{*}{13} & \multirow[t]{2}{*}{0,03} \\
\hline Classificação & \multicolumn{6}{|c|}{ Areia argilo siltosa } & & & & \\
\hline
\end{tabular}

MCT: Miniatura Compactada Tropical; LL: limite de liquidez; IP: índice de plasticidade; IG: índice de grupo; AASHTO 2004 (American Association of State Highways and Trasnportation Officials); W: umidade (ótima); MEAS: massa específica aparente máxima seca; CBR: Califórnia Bering ratio ou índice de suporte Califórnia; c': coeficiente associado à argilosidade do solo; e': índice que reflete o caráter laterítico do solo. 


\section{Reforço do sub-leito}

No projeto do novo pavimento considerou-se essencial reforçar o subleito, como forma de evitar o afundamento em trilha de roda (deformação permanente para todas as camadas) adotando-se o seguinte procedimento: mistura em pista de bica corrida de ardósia (pré-existente no leito da via, em condição de 'encascalhamento') com o solo in situ, em proporções iguais e numa espessura da ordem de $0,20 \mathrm{~m}$.

\section{Sub-base}

Construção de nova camada de sub-base, com mistura de solo-brita de ardósia em pista: brita 1, 20\%; brita 0, 20\%; pó de pedra, 30\%; e material terroso de área de empréstimo, em 30\%. Camada essa com 0,15m de espessura.

\section{Base}

Construção de nova camada de base, com mistura de solo-brita de ardósia em pista: brita 1, 20\%; brita 0,30\%; pó de pedra, 30\%; e material terroso de área de empréstimo, em $20 \%$. Camada essa com 0,15m de espessura. As composições granulométricas das camadas de base e sub-base foram enquadradas nas faixas C (DNIT - 141/2010) e D (DER-SP ET DE P00/008-2015), respectivamente. A Figura 5 destaca o enquadramento granulométrico referente à camada de base, principal camada granular.

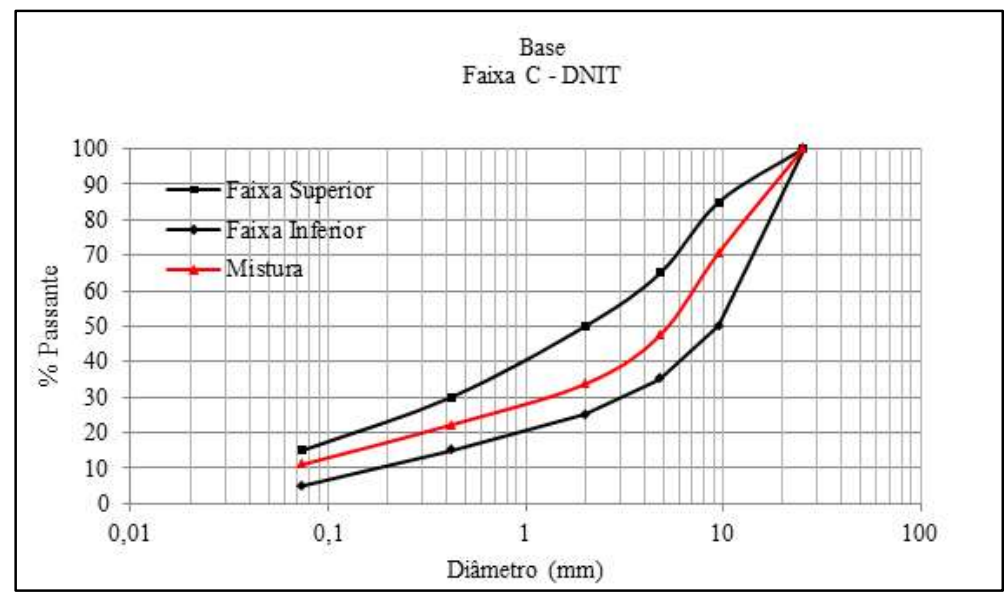

Figura 5: Composição granulométrica da base.

\section{Revestimento asfáltico com material britado e decantado (todos de ardósia)}

O revestimento ou capa asfáltica previsto para o trecho experimental foi projetado com $0,05 \mathrm{~m}$ de espessura, considerando-se duas misturas: Mistura 1, com brita 0 de ardósia possuindo índice de forma menor que a 0,5 (o que é mais comum), e outra, Mistura 2, com brita 0 de ardósia exclusivamente matação, possuindo índice de forma necessariamente superior a 0,5, por ser um agregado mais espesso em razão de sua diferenciada litologia.

Mistura 1: brita 1 (9,43\%); brita 0 (28,29\%); pó de pedra (37,72\%); pó decantado $(18,86)$; e CAP 50/70 (5,7\%), fornecido pela REGAP (Petrobrás), e aplicada em 137m de pista. Mistura 2: brita 0 de ardósia matacão $(37,72 \%)$, pó de pedra $(42,44 \%)$, pó decantado (14,14\%); e CAP $50 / 70(5,7 \%)$, fornecido pela REGAP 
(Petrobrás), aplicada em 123m de pista. De forma resumida, algumas etapas da construção da pista podem ser visualizadas na Figura 6-A. As camadas do pavimento projetadas e construídas estão representadas na figura 6-B.
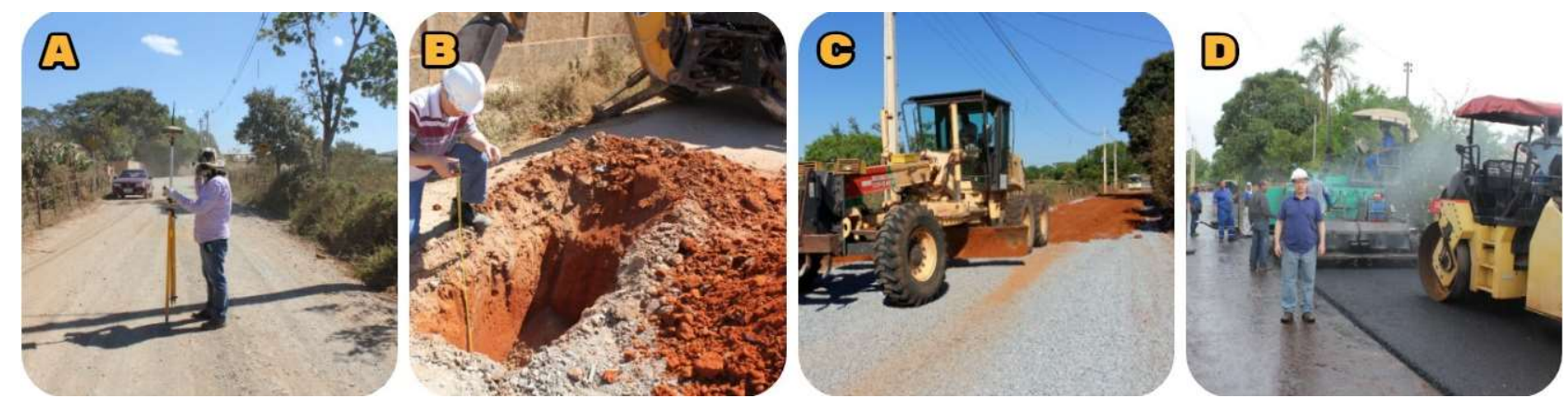

Figura 6-A: A) Levantamento topográfico; B) Abertura de trincheira para coleta de materiais; C) Mistura em pista de agregados de ardósia e solo; e D) Construção da camada de rolamento (revestimento).

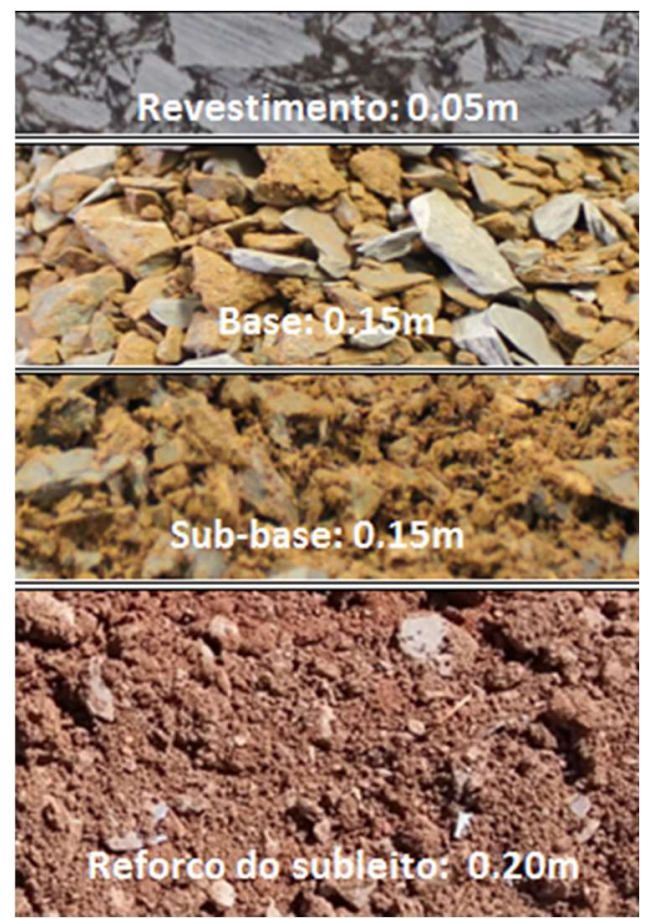

Figura 6-B: Perfil do Pavimento.

\section{RESULTADOS}

Os parâmetros geotécnicos antes e depois da estabilização granulométrica podem ser comparados à vista da Tabela 4.

Com relação à base, após estabilização granulométrica, houve, em princípio, um 'prejuízo' em termos de plasticidade, uma vez que o leito primitivo da via, na extensão do trecho experimental, era constituído de bica corrida de ardósia (IP não plástico), passando então para IP = 8\%. A norma DNIT 141 (2010) determina que o índice de plasticidade, para base estabilizada granulometricamente, seja no máximo igual a $6 \%$. Contudo, a mesma norma admite IP maiores que 6\% quando o equivalente de areia do material for maior que $30 \%$, como no caso presente $(76,9 \%)$. Com exceção do IP referente à base, os demais parâmetros tiveram suas propriedades geotécnicas melhoradas com a estabilização granulométrica, principalmente o CBR, sobretudo o da própria base, que variou de 70 para $130 \%$. 
Tabela 4: Comparação entre parâmetros geotécnicos antes e depois da estabilização granulométrica.

\begin{tabular}{|c|c|c|c|c|c|c|c|c|c|}
\hline CAMADAS & $\begin{array}{l}\mathrm{LL} \\
\%\end{array}$ & $\begin{array}{l}\text { IP } \\
\%\end{array}$ & IG & $\begin{array}{l}\text { AASTHO } \\
\text { Grupo }\end{array}$ & $\begin{array}{l}\text { W ótima } \\
\%\end{array}$ & $\begin{array}{l}\text { MEAS } \\
\mathrm{g} / \mathrm{cm}^{3}\end{array}$ & $\begin{array}{l}\text { CBR } \\
\% \\
\end{array}$ & $\begin{array}{l}\text { Expansão } \\
\% \\
\end{array}$ & $\begin{array}{l}\text { Energia } \\
\text { Proctor }\end{array}$ \\
\hline $\begin{array}{l}\text { Subleito } \\
\text { Primitivo }\end{array}$ & 47 & 20 & 13 & A-7-6 & 27,5 & 1.415 & 10 & 0,01 & Normal \\
\hline $\begin{array}{l}\text { Reforço } \\
\text { Subleito }\end{array}$ & 40 & 19 & 3 & $A-6$ & 13,3 & 1,816 & 16 & 0.04 & Intermediário \\
\hline $\begin{array}{l}\text { Sub-base } \\
\text { Primitiva }\end{array}$ & 35 & 17 & 3 & $A-6$ & 12,7 & 1,891 & 29 & 0,04 & Intermediário \\
\hline $\begin{array}{l}\text { Sub-base } \\
\text { Estabilizada }\end{array}$ & 26 & 11 & 0 & A-2-6 & 7,50 & 2,108 & 31 & 0 & Intermediário \\
\hline $\begin{array}{l}\text { Base } \\
\text { Primitiva }\end{array}$ & NL & NP & 0 & $A-1-A$ & 5,9 & 2,264 & 70 & 0,01 & Modificado \\
\hline $\begin{array}{l}\text { Base } \\
\text { Estabilizada }\end{array}$ & 22 & 8 & 0 & $A-2-4$ & 5,4 & 2,224 & 130 & 0 & Modificado \\
\hline
\end{tabular}

LL: limite de liquidez; IP: índice de plasticidade; IG: índice de grupo; W: umidade (ótima); MEAS: massa específica aparente máxima seca; CBR: Califórnia Bering ratio ou índice de suporte Califórnia; AASHTO: Association of State Highway and Transportation Officials. NL: Não liquidez; NP: Não plástico.

Para a obtenção do módulo de resiliência (MR), em amostras de solo-brita, foi utilizado um equipamento triaxial de cargas repetidas, mostrado na Figura 7, da marca SIGEO, empregando-se uma combinação de várias tensões aplicadas. Os valores numéricos mostrados na última coluna da Tabela 5 estão condizentes com a aplicação do modelo resiliente linear, associado à tensão desviadora ( $\sigma d)$. Por sua vez, o modelo não linear ou Modelo Composto, está representado por uma expressão estatística, que conjuga simultaneamente os pares tensão desviadora $(\sigma d)$ e tensão confinante $(\sigma 3)$ e, finalmente, tem como resultado os módulos dos parâmetros de regressão $K 1, k 2, k 3$ e $R^{2}$. O modelo composto foi o que melhor apresentou resultados (coeficientes de correlação) em comparação como os modelos $\sigma 3$ (britas) e od (puramente argiloso), sendo este o mais representativo.

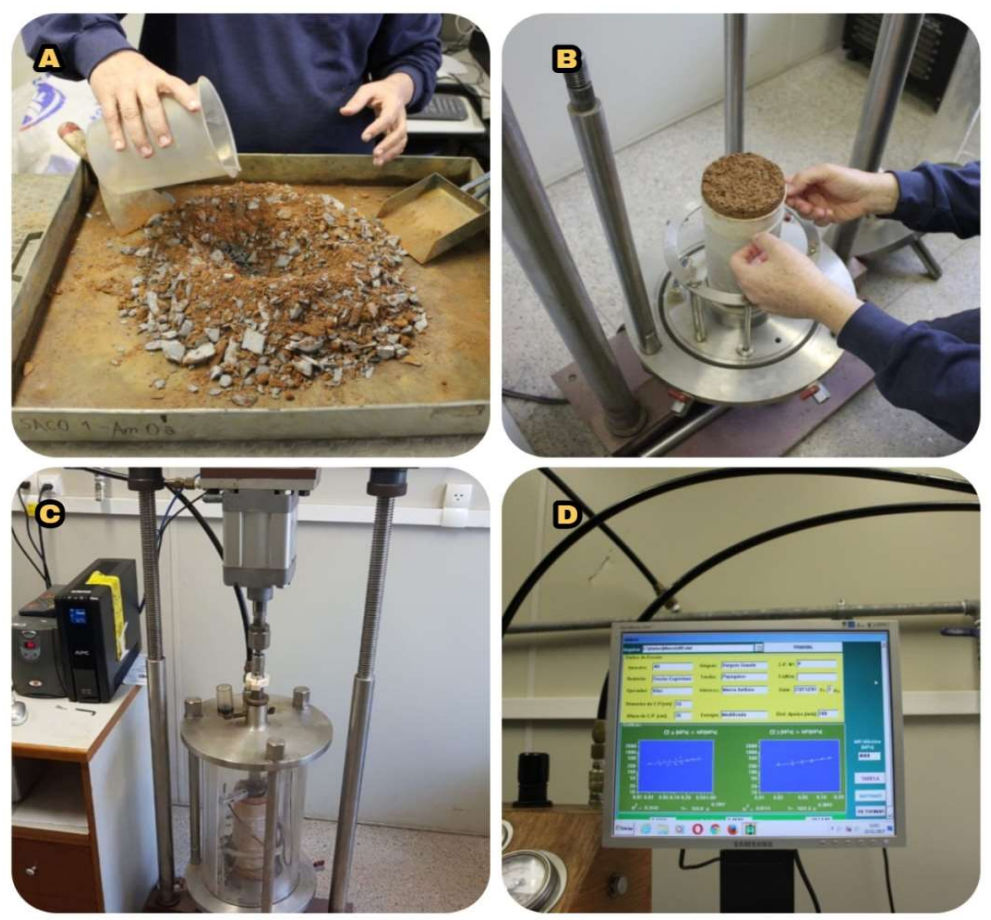

Figura 7: Procedimentos instrumentais para levantamento do módulo de resiliência e deformação permanente dos solos: A: Preparo da mistura solo-brita para formatação do corpo de prova-CP; B:Montagem dos LVDTs ; C: Equipamento triaxial dinâmico pronto para ensaio; D: Tela do sistema de aquisição de dados. 
Tabela 5: Módulos de resiliência das misturas granulares.

\begin{tabular}{|c|c|c|c|c|c|c|}
\hline \multirow{3}{*}{$\begin{array}{l}\text { Camadas } \\
\text { Granulares }\end{array}$} & \multicolumn{5}{|l|}{$\begin{array}{l}\text { Modelo Composto } \\
\text { Resiliente Não Linear }\end{array}$} & \multirow{3}{*}{$\begin{array}{l}\text { Modelo } \\
\text { Resiliente } \\
\text { Linear } \\
\text { MPa }\end{array}$} \\
\hline & \multirow{2}{*}{ Equação aplicável ao Modelo Composto } & \multicolumn{4}{|c|}{ Parâmetros de regressão } & \\
\hline & & K1 & K2 & K3 & $\mathbf{R}^{2}$ & \\
\hline \multirow{2}{*}{$\begin{array}{l}\text { Ref. Subleito } \\
\text { Sub-base }\end{array}$} & \multirow{3}{*}{$M R=k 1 \times \sigma 3 k 2 \times \sigma d k 3$} & 181,9411 & 0,4132 & $-0,4406$ & 0,9425 & 165 \\
\hline & & 398,2635 & 0,4244 & $-0,2541$ & 0,4070 & 192 \\
\hline Base & & 132,2536 & 0,118 & $-0,4306$ & 0,5644 & 220 \\
\hline
\end{tabular}

Com o referido equipamento triaxial de carga repetida, o mesmo tipo de amostra (composição) de solo-brita e também com o mesmo padrão de corpo de prova (dimensões e energia de compactação); porém com outro software, foi realizado outro ensaio com vistas à obtenção da deformação permanente para cada uma das camadas granulares e cujos parâmetros de deformabilidade encontrados $(\psi 1, \psi 2, \psi 3$ e $\psi 4)$, previstos no modelo de Guimarães (2009), foram obtidos também por meio de análise estatística (regressão não linear) e estão apresentados na Tabela 6.

Tabela 6: Deformação permanente de solos estabilizados granulometricamente.

\begin{tabular}{|c|c|c|c|c|c|c|}
\hline \multirow{2}{*}{$\begin{array}{l}\text { Camadas } \\
\text { Granulares }\end{array}$} & \multirow{2}{*}{$\begin{array}{l}\text { Classificação Laboratorial } \\
\text { Rodoviária - AASHO }\end{array}$} & \multicolumn{5}{|c|}{ Parâmetros de regressão } \\
\hline & & $\Psi_{1}$ & $\boldsymbol{\Psi} 2$ & $\boldsymbol{\psi}_{3}$ & $\Psi 4$ & $\mathbf{R}^{2}$ \\
\hline Ref. Subleito & $\begin{array}{l}\text { Argila arenosa com pedregulho } \\
\text { A-6 }\end{array}$ & 0,020 & 1,595 & 0,218 & 0,067 & 0,9 \\
\hline Sub-base & $\begin{array}{l}\text { Pedregulho areno argiloso } \\
\text { A }-2-6\end{array}$ & 0,012 & 1,490 & $-0,230$ & 0,077 & 0,9 \\
\hline Base & $\begin{array}{l}\text { Pedregulho areno argiloso } \\
\text { A }-2-4\end{array}$ & 0,001 & 2,745 & $-0,266$ & 0,093 & 0,9 \\
\hline
\end{tabular}

Para as misturas asfálticas, foi empregada a metodologia Marshall, a mais difundida no Brasil, seja no meio universitário, seja no profissional. A especificação de serviço vigente para concreto asfáltico aplicado em estradas de rodagem DNIT 031 (2006) estipula o ensaio Marshall para controle das misturas a quente. Para a dosagem Marshall, Misturas 1 e 2, foram confeccionados quinze corpos de prova, sendo três para cada teor de asfalto. Na Tabela 7 estão apresentados os valores médios representativos do teor ótimo de betume para cada uma das duas misturas, bem como o resultado encontrado por outros pesquisadores para essa mesma dosagem, como Silva (2017), Prudente (2015) e Pires (2006).

Tabela 7: Dosagem Marshall.

\begin{tabular}{lllllllll}
\hline Referência & $\begin{array}{l}\text { Agregado } \\
\text { rocha }\end{array}$ & $\begin{array}{l}\text { CAP } \\
\%\end{array}$ & $\begin{array}{l}\text { Densidade } \\
\text { Aparente }\end{array}$ & $\begin{array}{l}\text { Densidade } \\
\text { Teórica }\end{array}$ & $\begin{array}{l}\text { Vv } \\
\%\end{array}$ & $\begin{array}{l}\text { VAM } \\
\%\end{array}$ & $\begin{array}{l}\text { RBV } \\
\%\end{array}$ & $\begin{array}{l}\text { Estabilidade } \\
\text { kgf }\end{array}$ \\
\hline (Mistura 1) & Ardósia & $50 / 70(5,7)$ & 2,432 & 2,522 & 3,59 & 17,26 & 79,22 & 855 \\
\hline (Mistura 2) & Ardósia & $50 / 70(5,7)$ & 2,420 & 2,513 & 3,69 & 17,29 & 78,67 & 900 \\
\hline Silva (2017) & Gnaisse & $50 / 70(5,0)$ & 2,378 & 2,468 & 3,5 & 15,46 & 76,40 & 1558 \\
\hline Prudente (2015) & Granito/Gnaisse & $50 / 70(5,3)$ & 2,438 & 2,553 & 4,00 & 16,50 & 76,70 & 1247 \\
\hline Pires (2006) & Ardósia & $20(4,9)$ & 2,417 & 2,497 & 3,2 & 15,10 & 78,7 & 1117 \\
\hline DNIT 031 (2006) & Especificação para camada de rolamento & & $3-5$ & $>15$ & $75-83$ & $\geq 500$ \\
\hline
\end{tabular}

CAP: cimento asfáltico de petróleo; Vv: volume de vazios; VAM: vazios do agregado mineral; RBV: relação betumevazios.

Com o teor ótimo de betume definido pela metodologia Marshall, para cada uma das Misturas Asfálticas 1 e 2, foram moldados três corpos de prova para ensaio de tração por compressão diametral, três corpos de prova para ensaio de módulo de resiliência e 5 corpos de prova para ensaio de vida de fadiga. Esses corpos de prova foram submetidos a ensaios de natureza mecânica (prensa automatizada, marca 
SOILTEST, para determinação da tração por compressão diametral) e dinâmica (equipamento destinado à compressão diametral de cargas repetidas e sistema de aquisição de dados (marca SIGEO) para determinação de módulo de resiliência e vida de fadiga). A Figura 8 mostra corpos de prova submetidos aos referidos ensaios.
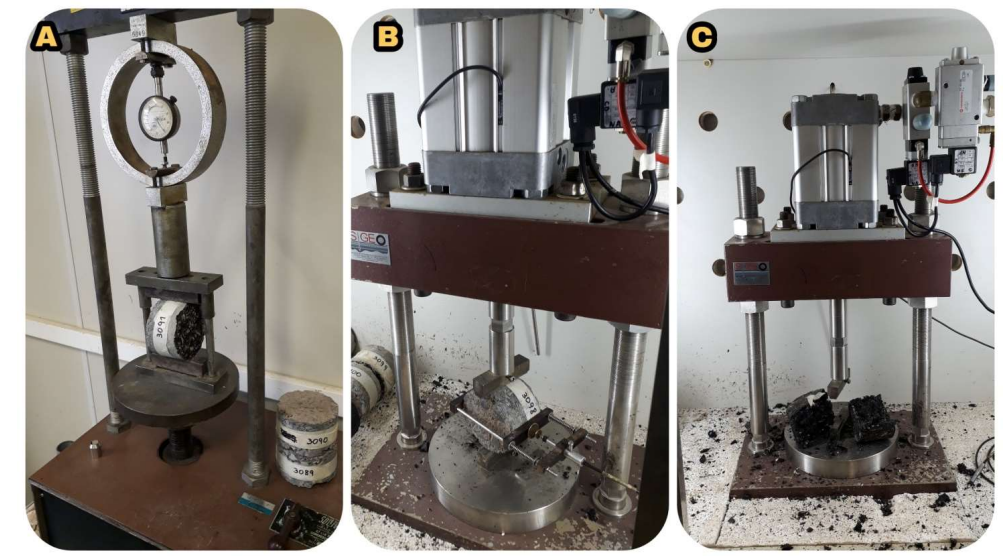

Figura 8: Ensaios mecânicos em misturas asfálticas: A: Resistência à Tração; B: Módulo de Resiliência; C: Fadiga.

O resultado dos ensaios mecânico e dinâmicos para as Misturas Asfálticas 1 e 2 está apresentado na Tabela 8 com valores médios, associados aos parâmetros tração indireta por compressão diametral, módulo de resiliência, razão entre módulo de resiliência e tração e vida de fadiga. Nessa tabela está mostrado também o resultado encontrado por outros pesquisadores, para os mesmos parâmetros em foco.

Tabela 8: Resultado dos ensaios mecânicos das misturas asfálticas.

\begin{tabular}{|c|c|c|c|c|c|c|}
\hline Referência & $\begin{array}{l}\text { Tipo } \\
\text { Agregado }\end{array}$ & $\begin{array}{l}\text { CAP } \\
\%\end{array}$ & $\begin{array}{l}\text { RT } \\
\mathrm{MPa}\end{array}$ & $\begin{array}{l}\mathrm{MR} \\
\mathrm{MPa}\end{array}$ & MR/RT & $\begin{array}{r}\text { FADIGA } \\
R^{2}\end{array}$ \\
\hline Mistura 1 & Ardósia & $50 / 70(5,7)$ & 1,66 & 8.182 & 4.929 & 0,96 \\
\hline Mistura 2 & Ardósia & $50 / 70(5,7)$ & 1,44 & 6.313 & 4.384 & 0,93 \\
\hline Silva (2017) & Gnaisse & $50 / 70(5,0)$ & 1,46 & 6.431 & 4.405 & 0,98 \\
\hline Prudente (2015) & Granito/ Gnaisse & $50 / 70(5,3)$ & 1,06 & 5.723 & 5.399 & \\
\hline Silva (2010) & Gnaisse & $50 / 70(5,8)$ & 1,36 & 4.478 & 3.293 & 0,99 \\
\hline
\end{tabular}

O resultado gráfico dos ensaios de vida de fadiga e sua expressão estatística (regressão linear) estão mostrados nas Figura 9 e 10. No Programa MeDiNa, o parâmetro deformação específica resiliente (er) é utilizado na rotina de cálculo para determinar a vida de fadiga, e o parâmetro diferença de tensões ( $\Delta \sigma)$. Vida de fadiga à tensão constante é a forma mais comumente usada no Brasil para avaliação de misturas asfálticas ao trincamento.
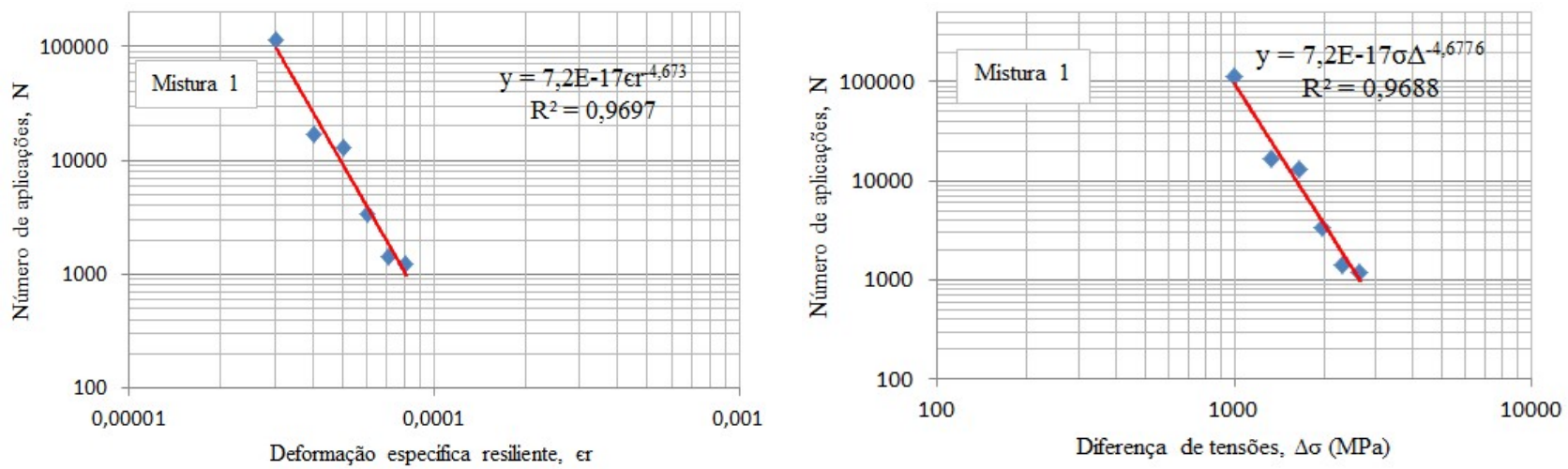

Figura 9: Vida de Fadiga da Mistura 1: deformação específica resiliente $(\epsilon r)$ e diferença de tensões $(\Delta \sigma)$. 

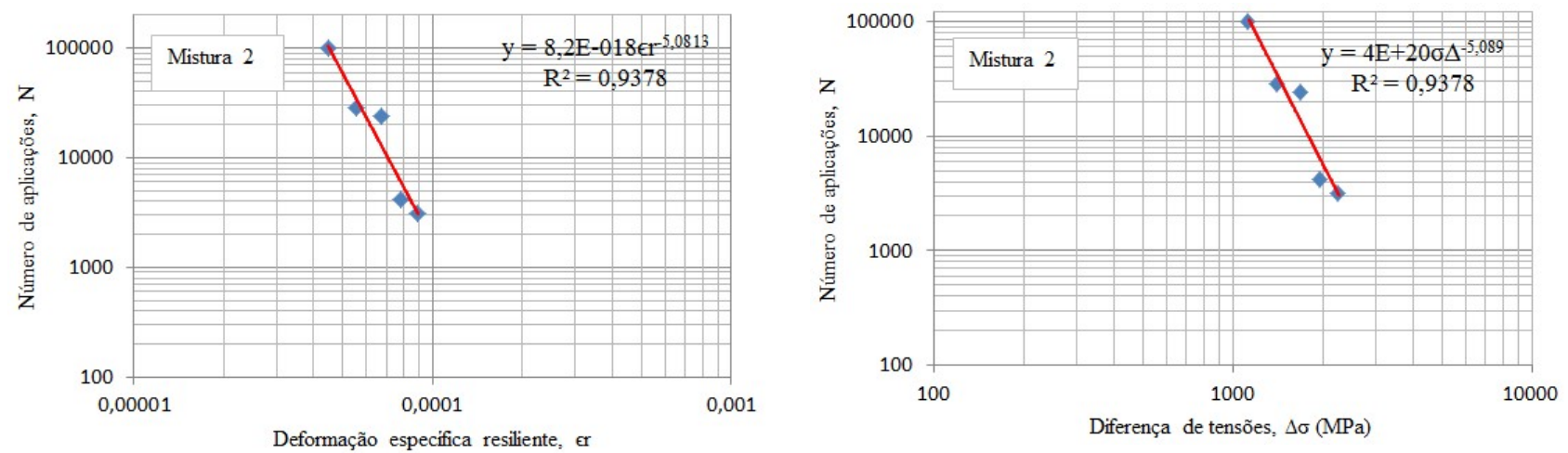

Figura 10: Vida de Fadiga da Mistura 2: deformação específica resiliente ( $\epsilon r)$ e diferença de tensões $(\Delta \sigma)$.

Com os elementos técnicos do projeto do novo pavimento do trecho experimental e dos parâmetros geotécnicos, mecânicos e mecanístico-empíricos, levantados por meio dos ensaios mencionados, foi aplicado o Programa MeDiNa (nível de confiabilidade da análise de 65\%; volume médio diário para o 10 ano de 25 veículos-padrão; e período de projeto de 10 anos), o qual mostrou, para a Mistura Asfáltica 1, área trincada de 1,5\% e 0,00 mm para afundamento em trilha de roda. Para a Mistura Asfáltica 2, área trincada de 1,4\% e $0,00 \mathrm{~mm}$ para afundamento em trilha de roda. A Figura 11 mostra a tela principal do programa MeDiNa, com o resultado do dimensionamento alusivo à mistura asfáltica 2.

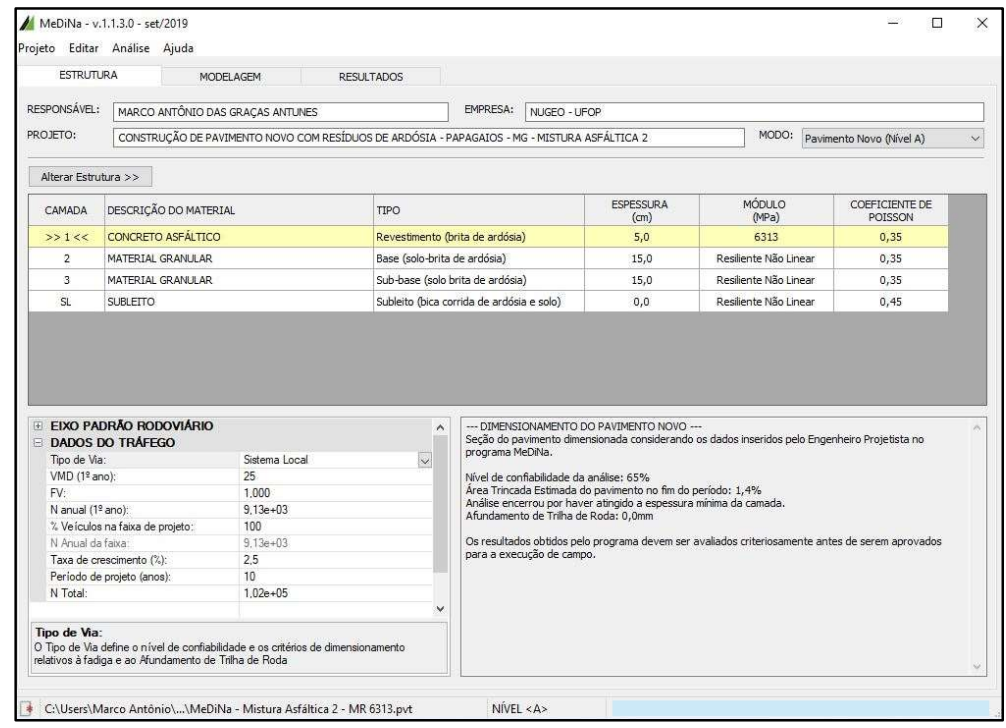

Figura 11: Tela principal do programa MeDiNa

\section{DISCUSSÃO}

O resultado do ensaio para a determinação do índice de forma (IF) mostrou que somente o agregado brita 0 (resíduo de ardósia, misturado) apresentou IF menor que 0,5 ( sendo o limite aceitável acima de 0,5, conforme DNER 086 (1994); ainda assim com valor 'tangente' (0,49). Ardósia matacão, variedade litológica da rocha que não apresenta subdivisão reprodutível ( a delaminação em placas não ocorre com as mesmas espessuras), conduz a britagem de agregados (brita 1 e brita 0) mais espessos e, portanto, menos alongados e não essencialmente lamelares. Essa condição diferenciada da rocha proporcionou à brita 1 e à brita 0 um IF de 0,74 e 0,54 , respectivamente. Mesmo que o resultado do ensaio de índice de forma conduzisse a valor inferior ao limite mínimo, Pinto et al. (2015) admitem a presença de agregados com formas lamelares ou 
alongadas em massa asfáltica quando se tratar de revestimento por mistura, que é o caso presente.

A absorção do agregado graúdo, em 0,57\%, representou a média aritmética de duas determinações consecutivas: $0,47 \%$ e $0,67 \%$. Para agregados com absorção inferior a $2 \%$ (baixa porosidade), a norma do DNER-ME 195 (1997) estipula como aceitável que o resultado de duas determinações sequenciais, com amostra do mesmo agregado, não deva diferir em mais de $0,25 \%$, o que de fato procedeu.

As normas DNIT 031 (2006), especificação de serviço para concreto asfáltico, e DNIT 141 (2010), especificação de serviço para base estabilizada granulometricamente, determinam em regra um desgaste abrasivo para o agregado graúdo igual ou inferior a $50 \%$ e 55\%, respectivamente. O ensaio para determinação da resistência abrasiva do agregado graúdo de ardósia mostrou um baixo desgaste, de 17,6\%, após 500 revoluções do tambor da máquina Los Angeles.

Não obstante os agregados graúdos de ardósia apresentarem baixo desgaste abrasivo, foram realizados mais outros dois ensaios, segundo a norma DNER-ME 401 (1999), o que corroborou essa boa propriedade: Índice de degradação com ligante - IDML e Índice de degradação sem ligante - IDM. Para o primeiro, foi apurado IDML = 1,34\%; para o segundo, IDM = 2,1\%. A norma DNIT 031 (2006), para concreto asfáltico, impõe IDML $\leq 5 \%$ e IDM $\leq 8 \%$.

Os agregados britados de ardósia mostraram-se resistentes ao ataque pelo sulfato de magnésio, comprovando sanidade à desintegração química. A avaliação da durabilidade foi procedida pelo ensaio correspondente à norma DNER 089 (1994), cujo resultado mostrou um desgaste de 0,27\% (muito baixo). A norma DNIT 031 (2006) preconiza um desgaste inferior a 12\% como aceitável.

A mistura de ardósia nas frações brita 1, brita 0 e pó de pedra (BGS) e solo, proporcionou considerável melhora na qualidade geotécnica dos materiais, em termos gerais, se comparados antes e depois da estabilização granulométrica. Essa providência teve como intuito obter-se o necessário imbricamento entre as partículas solo - brita de forma que o esqueleto mineral das misturas granulares das camadas de base e sub-base apresentasse graduação densa (curva granulométrica contínua). Para avaliar a qualidade de um solo destinado às camadas de base ou sub-base, utiliza-se o parâmetro IG, cuja propriedade está diretamente relacionada à plasticidade. Solos com IG = 0 são considerados excelentes para essas funcões.

Feito o ensaio de equivalente de areia, para a fração pó de pedra de ardósia, resultou 76,9\% (Tabela 1), percentual este inclusive superior ao limite mínimo previsto para uso desse tipo de agregado na camada de revestimento, em concreto asfáltico, que é de 55\% DNIT - 031 (2006). Na aplicação do Método MeDiNa , no tocante a utilização do módulo de resiliência - solos, preferiu-se utilizar o modelo composto (elástico não linear, com uso simultâneo dos parâmetros $\sigma 3$ e $\sigma$ d) ao modelo linear (com uso de $\sigma 3$ ou $\sigma d$ ), em razão de que o comportamento de materiais granulares, que é o caso, sob carregamento repetido, é comprovadamente elástico não linear Motta (1991).

A adesividade ao ligante asfáltico CAP 50/70 foi atestada visualmente, ao final da execução do ensaio apresentado na norma DNER- 078 (1994). Por não ter sido constatado qualquer deslocamento de película betuminosa que envolvia completamente os agregados graúdos, o resultado foi anotado com indicação 'satisfatória', entre as indicações previstas (má, satisfatória, boa e ótima) nesse ensaio. 


\section{CONCLUSÕES}

Os agregados britados de ardósia, nas frações brita 1, brita 0 e pó de pedra, enquanto materiais pétreos em si, mostraram-se resistentes ao desgaste físico (amassamento e impacto) e químico. Enquanto em misturas, solo-brita e brita-ligante asfáltico, demonstraram bom funcionamento em um sistema múltiplo de camadas, sob o ponto de vista estrutural (resistência e rigidez) e sob o ponto de vista mecanístico (mediante carregamento cíclico).

O conceito ainda presente no meio técnico rodoviário de que o material britado de ardósia, por ser de natureza 'lamelar', não é um impeditivo em si para seu uso, conforme ficou demonstrado nos ensaios e na aplicação em campo, inclusive sob a visão mecanicista moderna. A avaliação objetiva e funcional da pista do trecho experimental, aos seis meses de sua liberação ao tráfego, não registrou quaisquer ocorrências aparentes na superfície do pavimento, como desagregação do concreto asfalto, trincas isoladas (transversais, longitudinais) ou interligadas (tipo 'jacaré') e nem outras patologias como afundamentos localizados ou em trilhas de roda.

A utilização de agregados britados de ardósia em vias de comunicação e transporte, na região central de Minas Gerais, além de proporcionar emprego e renda, concorrerá necessariamente para a sustentabilidade ambiental, evitando-se a exploração de mais pedreiras (materiais tradicionais) na região, com seus inevitáveis e graves impactos para o meio ambiente.

Cabe aos agentes públicos, privados e a sociedade como um todo, incentivar o desenvolvimento de pesquisas no sentido de promover a reutilização e a reciclagem de materiais, principalmente os inertes, muitos destes disponíveis e de fácil remoção e transformação imediata, caso das ardósias, como forma de torná-los economicamente atrativos, empregadores de mão de obra e eficientes à finalidade a que se destinam.

\section{REFERÊNCIAS}

AASHTO. American Association of State Highways and Transportation Officials. M145-91: Aggregate Mixtures for Highway Construction Purposes. Washington: AASHTO, 2004.

ABIROCHAS. Associação Brasileira da Indústria de Rochas Ornamentais. Guia de aplicação de rochas de revestimentos: Projeto Bula. São Paulo: ABIROCHAS, 2009.

ABNT. Associação Brasileira de Normas Técnicas. NBR 6459: Determinação do limite de liquidez. Brasília: ABNT, 2016.

ABNT. Associação Brasileira de Normas Técnicas. NBR 6557: Preparação para ensaio de solos. Brasília: ABNT, 2016.

ABNT. Associação Brasileira de Normas Técnicas. NBR 7180: Determinação do limite de plasticidade. Brasília: ABNT, 2016.

ABNT. Associação Brasileira de Normas Técnicas. NBR 7181: Análise granulométrica por peneiramento. Brasília: ABNT, 2016.
ABNT. Associação Brasileira de Normas Técnicas. NBR 7182: Solo: Ensaio de compactação. Brasília: ABNT, 2016.

ABNT. Associação Brasileira de Normas Técnicas. NBR 9895: Solo: Índice de suporte Califórnia (ISC), Método de ensaio. Brasília: ABNT, 2016.

BALBO, J. T.. Pavimentação asfáltica: materiais, projetos e restauração. São Paulo: Oficina de Textos, 2007.

BARKSDALE, R. D.. Laboratory Evaluation of Rutting in Base Course Materials. In: PROCEEDINGS OF THE THIRD INTERNATIONAL CONFERENCE ON STRUCTURAL DESIGN OF ASPHALT PAVEMENTS. Anais. London, 1972. p.161-174.

BERNUCCI, L. B.; MOTTA, L. M. G.; CERATTI, J. A. P.; SOARES, J. B.. Pavimentação Asfáltica: Formação básica para engenheiros. Rio de Janeiro: PETROBRAS, 2010.

DAWSON, A.; NUNES, M.. Some British experience of the behaviour of furnace bottom ash and slate waste for pavement foundations. In: CONFERENCE: SYMPOSIUM ON RECOVERY AND EFFECTIVE REUSE OF DISCARDED 
MATERIALS AND BY-PRODUCTS FOR CONSTRUCTION OF HIGHWAY FACILITIES, AT DENVER, CO, USA. Anais. 1993.

DER. Departamento Estadual de Estrada de Rodagem de São Paulo. DER-SP ET-DE: P00/008: Sub-base estabilizada granulometricamente. São Paulo: DER 2015.

DNER. Departamento Nacional de Estradas de Rodagem. DNER 035: Agregados, determinação da abrasão "Los Angeles". Brasília: DNER, 1998.

DNER. Departamento Nacional de Estradas de Rodagem. DNER 043: Misturas betuminosas a quente, ensaio Marshall. Brasília: DNER, 1995

DNER. Departamento Nacional de Estradas de Rodagem. DNER 054: Equivalente de areia. Brasília: DNER, 1997.

DNER. Departamento Nacional de Estradas de Rodagem. DNER 078: Agregado, adesividade a ligante betuminoso. Brasília: DNER, 1994.

DNER. Departamento Nacional de Estradas de Rodagem. DNER 084: Agregado miúdo, Determinação da densidade real. Brasília: DNER, 1995.

DNER. Departamento Nacional de Estradas de Rodagem. DNER 086: Agregado, determinação do índice de forma. Brasília: DNER, 1994

DNER. Departamento Nacional de Estradas de Rodagem. DNER 089: Agregados, avaliação da durabilidade pelo emprego de soluções de sulfato de sódio ou de magnésio. Brasília: DNER, 1994.

DNER. Departamento Nacional de Estradas de Rodagem. DNER 152: Agregado em estado solto, determinação da massa unitária. Brasília: DNER, 1995.

DNER. Departamento Nacional de Estradas de Rodagem. DNER 195: Agregado, determinação da absorção e da massa específica de agregado graúdo. Brasília: DNER, 1997.

DNER. Departamento Nacional de Estradas de Rodagem. DNER 401: Agregados, determinação do índice de degradação de rochas após compactação Marshall, com ligante, IDML e sem ligante, IDM. Brasília: DNER, 1999.

DNER. Departamento Nacional de Estradas de Rodagem. Manual de Pavimentação. 2 ed. Rio de Janeiro: Instituto de Pesquisas Rodoviárias, 1996.

DNER. Departamento Nacional de Estradas de Rodagem. DNER 256: Solos compactados com equipamento miniatura: determinação da perda de massa por imersão: Método de Ensaio. Brasília: DNER, 1994.

DNER. Departamento Nacional de Estradas de Rodagem. DNER 258: Solos compactados em equipamento miniatura: Mini-MCV: Método de Ensaio. Brasília: DNER, 1994.

DNIT. Departamento Nacional de Infraestrutura de Transportes. MeDiNa, Método de Dimensionamento Nacional de Pavimentos. Versão Beta 1.1.2.0 (abr./2019). Brasília: DNIT, 2019.

DNIT. Departamento Nacional de Infraestrutura de
Transportes. DNIT 134: Pavimentação, Solos, Determinação do módulo de resiliência. Brasília: DNIT, 2018.

DNIT. Departamento Nacional de Infraestrutura de Transportes. DNIT 135: Pavimentação asfáltica, Misturas asfálticas, Determinação do módulo de resiliência. Brasília: DNIT, 2018

DNIT. Departamento Nacional de Infraestrutura de Transportes. DNIT 136: Pavimentação asfáltica, Misturas asfálticas, Determinação da resistência à tração por compressão diametral. Brasília: DNIT, 2018.

DNIT. Departamento Nacional de Infraestrutura de Transportes. DNIT 141: Pavimentação: Base estabilizada granulometricamente, Especificação de serviço. Brasília: DNIT, 2010

DNIT. Departamento Nacional de Infraestrutura de Transportes. DNIT 160: Solos: determinação da expansibilidade. Brasília: DNIT, 2012.

DNIT. Departamento Nacional de Infraestrutura de Transportes. DNIT 179: Pavimentação, Solos, Determinação da deformação permanente. Brasília: DNIT, 2018

DNIT. Departamento Nacional de Infraestrutura de Transportes. DNIT 179: Pavimentação, Solos, Determinação da deformação permanente. Brasília: DNIT, 2018.

DNIT. Departamento Nacional de Infraestrutura de Transportes. DNIT 183: Ensaio de fadiga por compressão diametral à tensão controlada. Brasília: DNIT, 2018.

FRANCO, A. C. P.. Método de Dimensionamento Mecanístico-Empírico de Pavimentos Asfálticos - SisPav. Tese (Doutorado) - Universidade Federal do Rio de Janeiro, Rio de Janeiro, 2007.

GUIMARÃES, A. C. R.. Um Método Mecanístico Empírico para a Previsão da Deformação Permanente de Solos Tropicais Constituintes de Pavimentos. Tese (Doutorado) Universidade Federal do Rio de Janeiro, Rio de Janeiro, 2009.

IBGE. Instituto Brasileiro de Geografia e Estatística. Cidades. Rio de Janeiro: IBGE, 2020.

LIMA, C. D. A. D.. Estudo da Deformação Permanente de Duas Britas Graduadas para Uso em Camadas de Pavimentos. Dissertação (Mestrado) - Universidade Federal do Rio de Janeiro, Rio de Janeiro, 2016.

MARQUES, G. L. O.. Utilização do Módulo de Resiliência como Critério de Dosagem de Mistura Asfáltica: Efeito da Compactação por Impacto e Giratória. Tese (Doutorado) Universidade Federal do Rio de Janeiro, Rio de Janeiro, 2004.

MEDINA, J.; MOTTA, L. M. G.. Mecânica dos Pavimentos, 3 ed. Rio de Janeiro: Interciência, 2015.

MOTTA, L. M. G.. Método de dimensionamento de pavimentos flexíveis: critério de confiabilidade e ensaios de cargas repetidas. Tese (Doutorado) - Universidade Federal do Rio de Janeiro, Rio de Janeiro, 1991.

NUNES, M. C. M.; BRIDGES, M. G.; DAWSON, A. R. Assessment Of Secondary Materials For Pavement 
Construction: Technical And Environmental Aspects. Waste Management, v.16, n.1-3, p.87-96, 1996.

PINTO, S.; PINTO, I. E.. Pavimentação asfáltica: conceitos fundamentais sobre materiais e revestimentos asfálticos. Rio de Janeiro: LTC, 2015.

PIRES, J. C. C.. Utilização dos rejeitos de ardósia para confecção de concreto betuminoso usinado a quente (CBUQ). In: REUNIÃO ANUAL DE PAVIMENTAÇÃO, 37; ENCONTRO NACIONAL DE CONSERVAÇÃO RODOVIÁRIA, 11. Anais. Goiânia, 2006.

PRUDENTE, C. Q. A.. Estudo Laboratorial De Misturas Asfálticas Aquente Utilizadas Em Goiás. Dissertação (Mestrado em Engenharia) - Universidade Federal de Goiás, Goiânia, 2015.

RODRIGUES, W. C.. Estudo sobre a viabilidade técnica e econômica da utilização de resíduo industrial de ardósia em misturas asfálticas do tipo pré-misturado a frio.

Dissertação (Mestrado) - Instituto Militar de Engenharia, Rio de Janeiro, 2009.

SILVA, R. G. O.. Caracterização de concreto asfáltico elaborado com rejeitos de minério de ferro do Quadrilátero Ferrífero. Tese (Doutorado em Geotecnia) - Universidade Federal de Ouro Preto, Ouro Preto, 2017.

SILVA, R. G. O.. Estudo laboratorial do desempenho mecânico de misturas asfálticas com resíduos industriais de minério de ferro. Dissertação (Mestrado) - Universidade Federal de Ouro Preto, Ouro Preto, 2010.

SOUZA JÚNIOR, J. G.. Aplicação do Novo Método de Dimensionamento de Pavimentos Asfálticos a Trechos de Uma Rodovia Federal. Dissertação (Mestrado) Universidade Federal do Rio de Janeiro, Rio de Janeiro, 2018.

A CBPC - Companhia Brasileira de Produção Científica (CNPJ: 11.221.422/0001-03) detém os direitos materiais desta publicação. Os direitos referem-se à publicação do trabalho em qualquer parte do mundo, incluindo os direitos às renovações, expansões e disseminações da contribuição, bem como outros direitos subsidiários. Todos os trabalhos publicados eletronicamente poderão posteriormente ser publicados em coletâneas impressas sob coordenação da Sustenere Publishing, da Companhia Brasileira de Produção Científica e seus parceiros autorizados. Os (as) autores (as) preservam os direitos autorais, mas não têm permissão para a publicação da contribuição em outro meio, impresso ou digital, em português ou em tradução. 